\title{
Pemberdayaan Karang Taruna Desa Gampingrowo dengan Pelatihan Hidroponik
}

\author{
Erlinda Ningsih*1, Agus Budianto², Kartika Udyani³ ${ }^{3}$ Yustia Wulandari M4, Shofiyya Julaika5, Dian \\ Yanuarita $\mathbf{P}^{6}$ \\ 1,2,3,4,5,6Institut Teknologi Adhi Tama Surabaya \\ ${ }^{3}$ Program Studi Teknik Kimia, Fakultas Teknologi Industri \\ *e-mail: erlindaningsih84@itats.ac.id ${ }^{1}$, budichemical@itats.ac.id $^{2}$
}

\begin{abstract}
The development of the property industry is very influential on the agricultural sector. Gampingrowo Village is an area where most of the people earn their living from agriculture. This relates to the availability of land if the land is used for the property industry. One alternative to overcome the limitations of agricultural land is to apply agricultural cultivation technology with the hydroponic method. The purpose of this service is to provide youth with skills, knowledge about hydroponics. This training method is carried out by providing counseling on hydroponic methods in general and training participants practice to assemble simple starter kits. Participants 25 people were divided into 3 groups where each group got 2 starter kit packages. The results of this dedication were that the participants were very enthusiastic and eager to know more about the hydroponic method with a few questions and they were very happy because the starter kit could be taken home.
\end{abstract}

Keywords: youth organization, empowerment, hydroponics, training, agriculture

\begin{abstract}
Abstrak
Perkembangan industri properti sangat berpengaruh terhadap sektor pertanian. Desa Gampingrowo merupakan daerah yang sebagian besar sumber pengasilan masyarakatnya dari pertanian. Hal ini berkaitan terhadap kesediaan lahan apabila lahan digunakan untuk industri properti. Salah satu alternatif untuk mengatasi keterbatasan lahan pertanian adalah menerapkan teknologi budidaya pertanian dengan metode hidroponik. Tujuan dari pengabdian ini adalah untuk memberikan keterampilan, pengetahuan kepada karang taruna tentang hidroponik. Metode pelatihan ini dilaksanakan dengan memberikan penyuluhan tentang metode hidroponik secara umum dan peserta pelatihan mempraktekkan untuk merangkai starter kit sederhana. Peserta 25 orang dibagi menjadi 3 kelompok di mana tiap kelompok mendapatkan 2 paket starter kit. Hasil dari pengabdian ini adalah peserta sangat antusias dan keinginan untuk mengetahui lebih banyak tentang metode hidroponik dengan beberapa pertanyaan dan mereka sangat senang karena starter kit bisa dibawa pulang.
\end{abstract}

Kata kunci: karang taruna,pemberdayaan,hidroponik,pelatihan,pertanian

\section{PENDAHULUAN}

Seiring perkembangan jaman dalam mengembangkan sektor pertanian mengalami banyak kendala. Kendala yang dialami diantaranya ketersediaan lahan yang sudah beralih fungsi menjadi pemukiman, hasil pertanian yang tidak sesuai karena hama dan penyakit, dan banyaknya pendatang yang bermukim di desa (Rudiana, 2017). Berdasarkan letak geografisnya Desa Gampingrowo merupakan dataran rendah sehingga sangat memungkinkan untuk pertanian dan sebagian besar penduduknya bermatapencaharian sebagai petani(Badan Pusat Statistik Kabupaten Sidoarjo,2018), lahan pertanian tersedia sebanyak 2089,24 hektar dan 1184,50 hektar sebagai pemukiman warga dari total sebesar 3605,97 hektar. Ketersediaan lahan pertanian berkurang selain akibat bertambahnya penduduk juga disebabkan karena banyak lahan pertanian yang dijual untuk dialih fungsikan menjadi perumahan oleh industri properti

Salah satu alternatif untuk mengatasi keterbatasan lahan pertanian adalah dengan metode hidroponik yang mana metode ini merupakan cara bercocok tanam memanfaatkan lahan sempit (Roidah, 2015), nutrisi yang diberikan mudah dan tidak menimbulkan polusi terhadap lingkungan (Halim \& I, 2019). Hidroponik merupakan aktivitas pertanian di mana penggunaan media tanah diganti dengan air tanpa memelukan lahan yang luas dan dapat memanfaatkan lahan pekarangan untuk mempecantik rumah, sumber pangan lestari dan ruang hijau (Hakimah \& 
Sardanto, 2017; Roidah, 2015). Banyak manfaat yang akan didapatkan dengan menerapkan metode hidroponik ini diantaranya perawatannya sangat mudah, masa panen yang lebih cepat, dapat memanfaatkan barang-barang yang sudah tidak digunakan lagi seperti ember, botol, baskom, dan sebagainya (Satya dkk., 2017). Di samping itu,tanaman yang dapat ditanam dengan metode hidroponik adalah tanaman jenis sayuran dan herbal, sehingga dapat meningkatkan ekonomi dan kesehatan masyarakat (Handayani, 2018). Pengenalan metode Hidroponik kepada masyarakat diharapkan dapat meningkatkan standar hidup layak, mencintai lingkungan, menumbuhkan kedasaran bahwa menanam tumbuhan tidak sulit dan tidak lama(Nugraha, 2019).

Karang taruna merupakan organisasi sosial di masyarakat yang berfungsi sebagai wadah untuk mengembangkan potensi pemuda dengan dengan kegiatan yang positif atas dasar kesadaran dan tanggung jawab sosial (Sarno, 2019). Kegiatan pemberdayaan terhadap karang taruna yang disesuaikan dengan kebutuhan dan karakteristik masyarakat untuk peningkatan pengembangan kemampuan menuju kemandirian. Diharapkan pelatihan hidroponik kepada karang taruna Desa Gampingrowo ini dapat meningkatka kreativitas pemuda menuju kemandirian ekonomi dalam bidang pertanian.

\section{METODE}

Dalam menyukseskan kegiatan pengabdian ini, perlu dilakukan observasi situasi dan karakteristik lokasi dan melakukan koordinasi awal dengan warga sekitar agar program yang ditawarkan kepada masyarakat Desa Gampingrowo sesuai dengan yang dibutuhkan. Untuk kegiatan pelatihan hidroponik yang dilaksanakan di balai Kelurahan Desa Gampingrowo ada dua tahapan yang dilakukan yaitu :

1. Ceramah, pada tahapan ini bertujuan untuk memberikan pengetahuan secara umum hidroponik. Dalam proses penyampaian ceramah ini dibantu dengan alat LCD agar lebih menarik peserta. Isi materi yang disampaikan meliputi : pengertian hidroponik, jenis jenis media dan sistem hidroponik, perawatan, kelebihan dan kekurangan hidroponik, dan hal - hal yang perlu diperhatikan dalam pemilihan bibit tanaman.

2. Demo, peserta melakukan praktek merakit starter kit yang sudah disediakan. Bahan bahan yang digunakan untuk pelatihan hidroponik ini adalah starter kit, rockwool, net pot, pipa, slang,, ring, ember, baskom, kain flannel, nutrient A, nutrient B, bibit tanaman sayur, dan pompa air.

\section{HASIL DAN PEMBAHASAN}

Kegiatan pelatihan ini berlangsung lancar dan baik. Semua peserta menunjukkan antusiasnya yang diwujudkan dalam beberapa pertanyaan dan berhasil merakit starter kit sampe proses menanam bibit sayuran. Acara pelatihan ini dilaksanakan di malam hari karena rata - rata para karang taruna Desa Gampingrowo memiliki kesibukan diantaranya kerja dan kuliah. Peserta yang datang merupakan perwakilan dari Karang Taruna 10 RT yang ada di Desa Gampingrowo, jumlah peserta adalah 25 orang. Untuk mempermudah dan memperlancar acara maka 25 peserta dibagi menjadi 3 kelompok di mana dalam 1 kelompok disiapkan 2 starter kit dan beberapa bahan lainnya. Pelaksanaan kegiatan ini melalui dua tahapan yaitu ceramah dan demo.

\section{Ceramah tentang hidroponik}

Peserta yang mengikuti pelatihan ini melakukan registrasi dan mendapatkan fotokopi materi, proses registrasi ini terlihat pada Gambar 1 . Sebanyak 25 peserta dibagi menjadi 3 kelompok untuk mengoptimalkan proses penyampaian materi. Peserta yang hadir tidak sesuai dengan target yang diharapkan di mana 25 dari 50 peserta. Meskipun peserta diluar prediksi namun pelaksanaannya lebih tertib dan fokus. Setelah proses pendataan peserta selesai, ceramah tentag hidroponik disampaikan. Penyampaian ceramah dengan sekitar 30 menit berlansung secara interaktif dan simple. 
Materi yang disampaikan adalah tentang pengetahuan umum tentang hidroponik, seperti pengertian, manfaat menerapkan metode hidroponik, dan metode ini merupakan solusi yang tepat untuk mengatasi ketersediaan lahan pertanian yang sudah terbatas tanpa menggunakan media tanah (Amri dkk., 2019). Selain hal umum tentang hidropinik, juga diberikan pengetahuan tentang 6 sistem hidroponik yaitu Sistem wick (sistem paling sederhana), sistem NFT (Nutrient Film Technique), sistem Floating Raft System (Rakit Apung), Drip System, dan sistem EBB dan Flow System (Flood and Drain) (Izzuddin, 2016). Teknik ini disampaikan agar para peserta memilih yang menurut mereka mudah dipraktekkan di rumah masing - masing. Diharapkan dengan penyampaian materi yang sesuai dengan kehidupan sehari - hari dapat diaplikasikan langsung dan nantinya dapat meningkatkan ekonomi masyarakat karena keterlibatan masyarakat (Saragih, 2020). Sebelum tahap ceramah berakhir, peserta diberi kesempatan untuk tanya jawab.

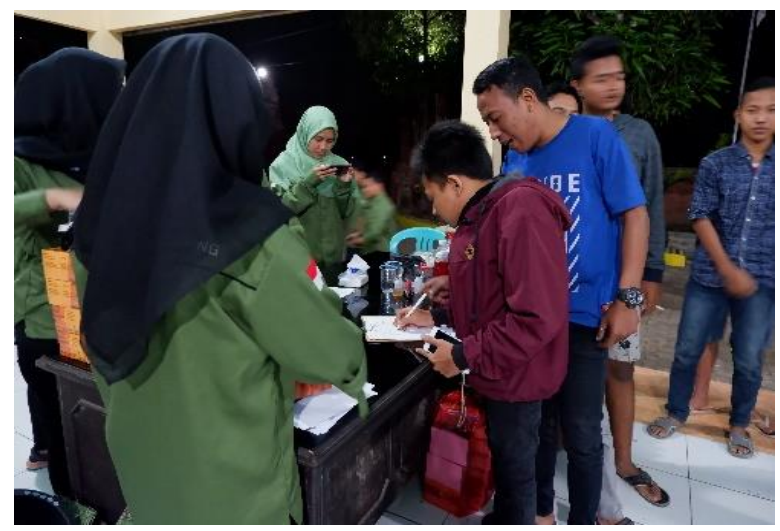

Gambar 1. Registrasi Peserta Pelatihan

\section{Demo merakit starter kit}

Tahap selanjutnya adalah tahap demo di mana semua peserta diberi kesempatan untuk merangkai starter kit dan semua bahan yang dibutuhkan sudah disediakan. Peserta menyiapkan baskom untuk dijadikan wadah air sebagai media, dengan dilubagi untuk sirkulasi air terlihat pada Gambar 2. Air yang dialirkan menggunakan pompa dengan perantara selang. Sementara peserta yang lain menyiapkan rockwool dan net pot.

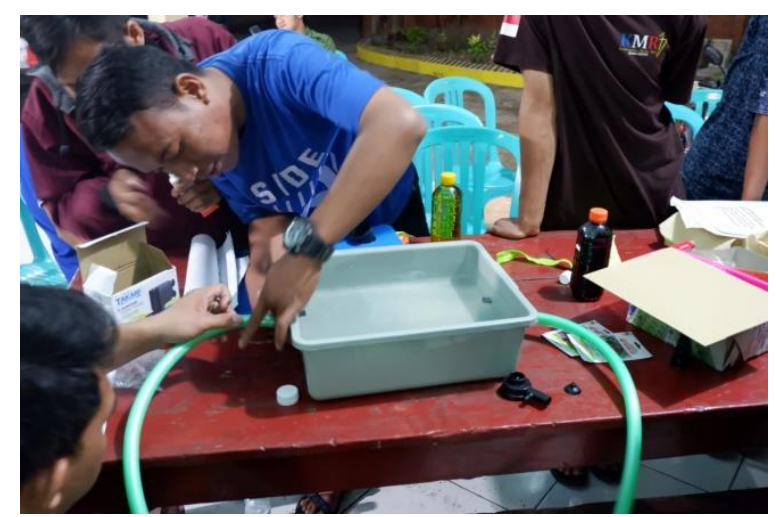

Gambar 2. Peserta Mulai Merakit Starter Kit

Penggunaan rockwool sebagai media tanamnya karena memiliki banyak kelebihan diantaranya tidak mengandung pathogen yang berpotensi menimbulkan penyakit pada tanaman, dapat menghemat penggunaan disinfektan, berperan optimal menggatikan pupuk, dapat dipergunakan berkali - kali dan yang sangat penting adalah penggunaan rockwool ini berpengaruh terhadap pertumbuhan dan hasil panen tanaman (Marlina dkk., t.t.). Rockwool yang sudah dipotong dilubangi dengan tusuk gigi sebagai tempat benih tanaman. Kemudian menyiapkan air dan pemberian nutrient yang dilanjutkan dengan menanam benih sayuran yang sudah disiapkan. 
Selama proses perakitan peserta didampingi oleh panitia dan bisa langsung bertanya jika ada kesulitan dalam proses merakit atau hal lain seputar hidroponik. Pelatihan ini sangat mudah dan praktis, sangat cocok dengan jiwa anak muda sekarang yang cenderung lebih memilih sesuatu hal yang simple dan cepat. Sehingga dapat merubah persepsi mereka tentang cara baru dalam bercocok tanam yang tidak harus bersusah payah menyiapkan lahan yang besar tapi produktivitas pertanian terus berjalan. Hasil rakit yang siap ditunggu panennya terlihat pada Gambar. 3 dapat dibawa pulang peserta. Untuk dapat mengembangkan di rumah masing - masing, peserta diarahkan menggunakan bahan bekas yang sudah tidak dipakai seperti botol plastik, ember, dan sebagainya, hal ini bertujuan untuk mengurangi polusi pencemaran lingkungan (sari dkk., 2017) dan secara tidak langsung dapat mengedukasi mereka untuk mendaur ulang limbah plastic (Mulasari, 2019).

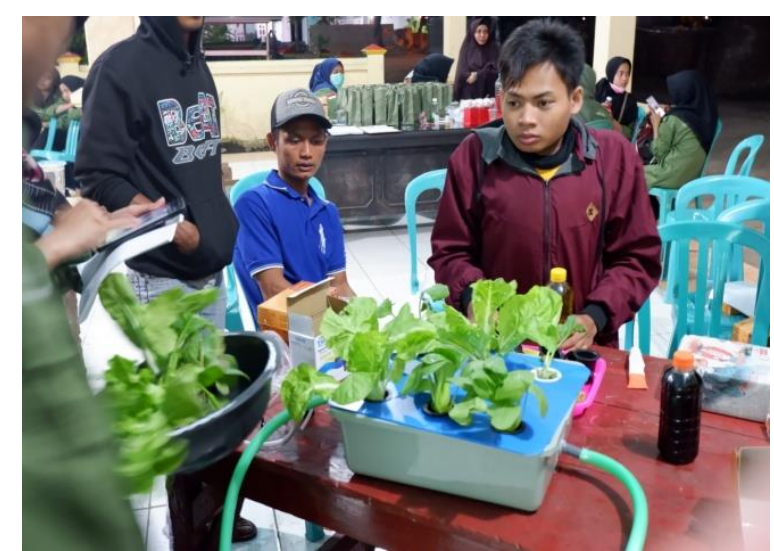

Gambar 3. Hasil Tanaman Hidroponik

\section{KESIMPULAN}

Metode budidaya tanaman dengan hidroponik merupakan salah satu alternative untuk mengatasi keterbatasan lahan pertanian. Pelaksanaan pengabdian ini berjalan dengan lancar dan sukses. Peserta pelatihan mendapatkan ilmu pengetahuan tentang metode hidroponik, teknik menanam hidroponik, keahlian merakit sederhana metode hidroponik, dan hasil perakitannya.

\section{UCAPAN TERIMA KASIH}

Penulis mengucapkan terima kasih kepada bapak Lurah Desa Gampingrowo atas kerjasamanya, warga sekitar dan Karang Taruna yang telah berpartisipasi dalam menyukseskan acara pengabdian ini.

\section{DAFTAR PUSTAKA}

Amri, A., Iqbal, A. M., \& Alimin, A. (2019). IbM BERCOCOK TANAM SECARA HIDROPONIK WARGA RT 05 RW 03 KELURAHAN PACCERAKKANG KECAMATAN MAKASSAR. Seminar Nasional Hasil Penelitian \& Pengabdian Kepada Masyarakat (SNP2M), O(0), 479-482.

Hakimah, E. N., \& Sardanto, R. (2017). PEMBERDAYAAN MASYARAKAT MELALUI PELATIHAN HIDROPONIK MEMBENTUK WIRAUSAHAWAN BARU PADA PERUM KUWAK UTARA KELURAHAN NGADIREJO KOTA KEDIRI. 1(1), 8.

Halim, L., \& I, Y. (2019). Strategi Pelatihan Hidroponik Sebagai Pemberdayaan Masyarakat Yang Bernilai Ekonomis. PATRIA, 1(2), 69. https://doi.org/10.24167/patria.v1i2.2069

Handayani, F. (2018). PELATIHAN BUDIDAYA SAYUR ORGANIK DAN TANAMAN HERBAL ORGANIK BERBASIS TEKNIK HIDROPONIK. 2, 8. 
Izzuddin, A. (2016). Wirausaha Santri Berbasis Budidaya Tanaman Hidroponik. Dimas: Jurnal $\begin{array}{llll}\text { Pemikiran Agama untuk } 351 . & \text { Pemberdayaan, }\end{array}$ https://doi.org/10.21580/dms.2016.162.1097

Marlina, I., Triyono, S., \& Tusi, A. (t.t.). PENGARUH MEDIA TANAM GRANUL DARI TANAH LIAT TERHADAP PERTUMBUHAN SAYURAN HIDROPONIK SISTEM SUMBU. $2,8$.

Mulasari, S. A. (2019). PENERAPAN TEKNOLOGI TEPAT GUNA (PENANAM HIDROPONIK MENGGUNAKAN MEDIA TANAM) BAGI MASYARAKAT SOSROWIJAYAN YOGYAKARTA. Jurnal Pemberdayaan: Publikasi Hasil Pengabdian Kepada Masyarakat, 2(3), 425-430. https://doi.org/10.12928/jp.v2i3.418

Nugraha, A. W. (2019). Pemberdayaan Masyarakat Desa Sumberdadi dengan Pelatihan Hidroponik dan Pupuk Organik. JPP IPTEK (Jurnal Pengabdian dan Penerapan IPTEK), 3(1), 25-32. https://doi.org/10.31284/j.jpp-iptek.2019.v3i1.481

Roidah, I. S. (2015). PEMANFAATAN LAHAN DENGAN MENGGUNAKAN SISTEM HIDROPONIK. Jurnal BONOROWO, 1(2), 43-49-49.

Rudiana, -. (2017). PENINGKATAN KAPASITAS LEMBAGA KEMASYARAKATAN DI RW 09 DESA MEKARGALIH MELALUI PELATIHAN TANAMAN HIDROPONIK. Jurnal Pengabdian Kepada Masyarakat, 1(3), Article 3. http://jurnal.unpad.ac.id/pkm/article/view/16390

Saragih, E. W. (2020). SISTEM PERTANIAN TERPADU DENGAN SISTEM KANDANG PADDOCK UNTUK MENINGKATKAN PENDAPATAN. Dinamisia : Jurnal Pengabdian Kepada Masyarakat, 4(1). https://doi.org/10.31849/dinamisia.v4i1.3735

sari, D. M. M., Prasetyo, Y., \& Kurniawan, A. (2017). METODE KONVERSI SAMPAH PLASTIK BERUPA BOTOL PLASTIK BEKAS MELALUI BUDIDAYA TOGA DENGAN SISTEM VERTIKULTUR YANG RAMAH LINGKUNGAN. Gontor Agrotech Science Journal, 3(2), 85-98.

Sarno, S. (2019). PEMBERDAYAAN KARANG TARUNA DESA RAKIT MELALUI KEGIATAN BUDIDAYA DAN PENGOLAHAN SAYURAN ORGANIK. Masyarakat Madani: Jurnal Kajian Islam dan Pengembangan Masyarakat, 4(2), 33-43.

Satya, M. T., Tejaningrum, A., \& Hanifah. (2017). Manajemen Usaha Budidaya Hidroponik. http://repository.ekuitas.ac.id/handle/123456789/335 